\title{
Plasma nitrate+nitrite levels are regulated by ovarian steroids but do not correlate with trabecular bone mineral density in rats
}

\author{
R L van Bezooijen 1, I Que ${ }^{1}$, A G H Ederveen², \\ H J Kloosterboer ${ }^{2}$, S E Papapoulos ${ }^{1}$ and C W G M Löwik ${ }^{1}$ \\ ${ }^{1}$ Department of Endocrinology and Metabolic Diseases, Leiden University Medical Center, PO Box 9600, 2300 RC, Leiden, The Netherlands and ${ }^{2}$ Department \\ of Endocrinology, Scientific Development Group, NV Organon, PO Box 20, 5340 BH, Oss, The Netherlands \\ (Requests for offprints should be addressed to R L van Bezooijen, Department of Endocrinology, Bldg1 C4-R86, Leiden University Medical Center, \\ PO Box 9600, 2300 RC, Leiden, The Netherlands)
}

\begin{abstract}
Nitric oxide (NO) is a mediator of bone metabolism and its production is under the control of gender hormones in several cell types or tissues. Changes in endogenous NO production, measured as plasma nitrate+nitrite levels, may therefore contribute to ovariectomy (OVX)-induced bone loss. We studied plasma nitrate + nitrite levels and trabecular bone mineral density (TBMD) 4 weeks after shamoperation or OVX in rats receiving various hormonal treatments. OVX decreased plasma nitrate+nitrite levels significantly and this was accompanied by a significant decrease in TBMD. Treatment with oral ethinyl oestradiol (EE) and subcutaneous $17 \beta$-oestradiol dose-dependently prevented the decrease in plasma nitrate+nitrite levels after OVX, but treatment with oral $17 \beta$-oestradiol did not. Oestrogen treatment, $17 \beta$-oestradiol (s.c. or orally) or EE (orally), prevented the OVX-induced decrease in TBMD. Treatment of sham-operated rats with the anti-oestrogen ICI164,384 induced a significant decrease in TBMD that
\end{abstract}

corresponded to $54 \%$ of the decrease observed after OVX, but did not affect plasma nitrate+ nitrite levels. Treatment of ovariectomized rats with Org 2058, a pure progestagen, did not prevent bone loss, but prevented the decrease in plasma nitrate + nitrite levels dose-dependently. Treatment with tibolone, a synthetic steroid with combined weak oestrogenic, progestagenic, and androgenic properties, or with progestagen in combination with EE completely prevented bone loss after OVX. These treatments, however, only partly prevented the OVX-induced decrease in plasma nitrate+nitrite levels. In conclusion, OVX decreased both TBMD and plasma nitrate+nitrite levels. Although plasma nitrate+nitrite levels were under the control of both oestrogen and progesterone, TBMD was affected by oestrogen only. Decreased systemic production of $\mathrm{NO}$ is, therefore, not involved in OVX-induced bone loss in rats.

Journal of Endocrinology (1998) 159, 27-34

\section{Introduction}

Loss of ovarian function is associated with bone loss as a consequence of an imbalance between bone resorption and formation in favour of the first. This can be prevented by oestrogen replacement. Progesterone may also be involved, as some progestagens have been shown to reduce postmenopausal bone loss (reviewed by Prior 1990). The mechanisms by which these ovarian steroids may exert their protective effect on bone are not well understood.

Nitric oxide (NO) may be involved in ovariectomy (OVX)-induced bone loss, as it modulates both osteoclastic bone resorption (MacIntyre et al. 1991, Stern \& Diamond 1992, Löwik et al. 1994, Ralston et al. 1995, Ralston \& Grabowski 1996) and osteoblast proliferation and activity (Damoulis \& Hauschka 1994, Ralston et al. 1994, Hukkanen et al. 1995, Riancho et al. 1995) in vitro and its production is regulated by gender-steroids in several cell types and tissues (Hayashi et al. 1992, 1995,
Weiner et al. 1994, Yallampalli et al. 1994). Administration of the NO-synthase (NOS) inhibitor aminoguanidine to rats induced bone loss (Kasten et al. 1994, Tsukahara et al. 1996) and reduced bone formation rate (Turner et al. 1997). The NOS inhibitors $\mathrm{N}^{\mathrm{G}_{-}}$ monomethyl-L-arginine (L-NMMA) and $\mathrm{N}^{\mathrm{G}}$-nitro-Larginine methyl ester (L-NAME) prevented the increase in cancellous bone formation by mechanical stimulation in rats (Fox et al. 1996, Turner et al. 1996). Treatment with the NO donor nitroglycerine prevented OVX-induced bone loss and administration of L-NAME completely blocked the preventive effect of oestrogen on OVXinduced bone loss (Wimalawansa et al. 1996). Nitrate+ nitrite $\left(\mathrm{NO}_{3}+\mathrm{NO}_{2}\right)$ plasma levels, which reflect endogenous NO production (Hibbs et al. 1992, Shultz \& Raij 1992), have been found to correlate positively with serum 17ß-oestradiol levels (Rosselli et al. 1994, 1995, Ramsay et al. 1995, Cicinelli et al. 1996, Kawano et al. 1996, Imthurn et al. 1997). On the other hand, progesterone 
may have a down-regulating effect on $\mathrm{NO}_{3}+\mathrm{NO}_{2}$ plasma levels in the presence of oestrogen (Rosselli et al. 1994, 1995, Cicinelli et al. 1996, Kawano et al. 1996, Imthurn et al. 1997).

In the present study, we hypothesized that loss of ovarian function causes a decrease in NO production, which in turn contributes to bone loss. To investigate this, sham-operated or ovariectomized rats were treated with various hormonal therapies and trabecular bone mineral density (TBMD) and $\mathrm{NO}_{3}+\mathrm{NO}_{2}$ plasma levels were determined 4 weeks after surgery.

\section{Materials and Methods}

\section{Animals and materials}

Mature 3-month-old unmated female Wistar rats (strain Hsd/Cpd:Wu), weighing approximately $225 \mathrm{~g}$, were obtained from Harlan, the Central Institute for Breeding of Laboratory Animals, Zeist, The Netherlands. The animals were housed under standard conditions and kept with a ratio of $14 \mathrm{~h}$ light: $10 \mathrm{~h}$ darkness in an air conditioned room $\left(21^{\circ} \mathrm{C} \pm 2{ }^{\circ} \mathrm{C}\right)$. During the experiment the animals were housed individually, had free access to tap water and were pair-fed (16 g pelleted food per day (Hope Farms, Linschoten, The Netherlands)). All protocols were approved by the Animal Ethics Committee. Animals were divided into groups according to a randomized block design using body weight as the selection parameter. Rats were subjected to either OVX $(n=140)$ or sham-operation $(n=72)$ under general anaesthesia. From the day of operation onwards, the ovariectomized rats received various hormonal treatments (twice daily), consisting of vehicle $(0.5 \% \mathrm{w} / \mathrm{v}$ gelatine and $5 \% \mathrm{w} / \mathrm{v}$ mannitol; $n=54)$, ethinyl oestradiol (EE) (orally; $n=6$ ), $17 \beta$-oestradiol (orally; $n=4$ 10 , s.c.; $n=8),(16 \alpha)$-16-ethyl-21-hydroxy-19-norpregn4-ene-3,20-dion (s.c.; Org 2058; $n=6$ ); a pure progestagen which exerts its effect via the progesterone receptor only, progestagen (s.c.) and EE (orally; $n=6$ ), or tibolone (orally; Org OD14: (7 $\alpha, 17 \alpha)-17-h y d r o x y-7-m e t h y l-19-$ norpregn-5(10)-en-20-yn-3-one; $n=12$ ) (de Visser et al. 1984). Sham-operated rats received control solution $(n=60)$, the anti-oestrogen ICI164,384 (s.c., $(7 \alpha, 17 \beta)-\mathrm{N}-$ butyl-3,17-dihydroxy-N-methylestra-1,3,5(10)-triene-7undecanamide; $n=6$ ) (Wakeling \& Bowler 1987) in arachis oil, or the anti-progestagen RU 486 (orally, $11 \beta$-(4-(dimethyl-amino)phenyl)-17 $\beta$-hydroxy-17 $\alpha$-(1propynyl)-estra-4,9-dien-3-one; $n=6$ ) (Baulieu 1989). All preparations were made by the Department of Pharmaceutics, N.V. Organon, Oss, The Netherlands and were of analytical grade. After 4 weeks treatment and overnight fasting, blood was collected from the abdominal aorta under general anaesthesia. Heparin plasma samples were centrifuged $(3000 \mathrm{~g})$ for $10 \mathrm{~min}$ at $4{ }^{\circ} \mathrm{C}$, divided into small samples, and stored at $-20{ }^{\circ} \mathrm{C}$. The right femora were dissected out for TBMD measurement at autopsy.

\section{Plasma nitrate + nitrite analysis}

Plasma samples were deproteinized with 3\% (final concentration) $\mathrm{ZnSO}_{4}$ for $15 \mathrm{~min}$ and centrifuged at $30000 \mathrm{~g}$ for 15 min. $\mathrm{NO}_{3}$ in supernatants was reduced to $\mathrm{NO}_{2}$ with oxidized cadmium in $0.56 \% \mathrm{NH}_{4} \mathrm{Cl}$ and $0 \cdot 15 \%$ Borax-buffer (Sigma, Zwijndrecht, The Netherlands) for $30 \mathrm{~min}$ and vortexed every $5 \mathrm{~min}$. Cadmium was oxidized by two treatments with $2 \% \mathrm{HCl}$ for $30 \mathrm{~min}$ under continuous shaking. Before oxidized cadmium was added to plasma supernatants, $\mathrm{pH}$ was neutralized by repeated washing with distilled water. $\mathrm{NO}_{2}$ levels in the reduced plasma supernatants were determined with Griess reagent consisting of $0.5 \%$ sulfanylamide, $0.05 \%$ naphthylethelene-diamine-dihydrochloride, and 2.5\% $\mathrm{H}_{3} \mathrm{PO}_{4}$. Equal volumes $(50 \mu \mathrm{l})$ of reduced samples and Griess reagent were mixed and incubated in a 96-well plate for $15 \mathrm{~min}$ at room temperature under continuous shaking. $\mathrm{NO}_{2}$ concentration, proportional to $\mathrm{OD}_{550}$, was determined using a microtiterplate reader (Thermomax, Molecular Devices, Menlo Park, CA, USA). Results are not differentiated into $\mathrm{NO}_{3}$ and $\mathrm{NO}_{2}$ but expressed as $\mathrm{NO}_{3}+\mathrm{NO}_{2}$ levels, as very little or no $\mathrm{NO}_{2}$ is present in plasma of humans (Green et al. 1982) and rats (own observation). The percentage of $\mathrm{NO}_{3}$ that was reduced to $\mathrm{NO}_{2}$ was extrapolated from comparing standard curves of serial dilutions of $\mathrm{NaNO}_{3}$ and $\mathrm{NaNO}_{2}$ which had undergone the same procedure as the plasma samples. $\mathrm{NO}_{3}+\mathrm{NO}_{2}$ concentrations of the plasma samples were estimated from the $\mathrm{NaNO}_{3}$ standard curve and corrected for the percentage $\mathrm{NO}_{3}$ reduction to $\mathrm{NO}_{2}$. The mean percentage $\mathrm{NO}_{3}$ reduction to $\mathrm{NO}_{2}$ was $72 \cdot 7 \% \pm 2 \cdot 2$ (range 64-79). The mean correlation coefficients of the $\mathrm{NaNO}_{3}$ and $\mathrm{NaNO}_{2}$ standard curves were $0.998 \pm 0.001$ (range 0.992-1.000) and 0.997 \pm 0.001 (range 0.9900.999) respectively.

\section{Trabecular bone mineral density}

TBMD $(\mathrm{mg} / \mathrm{cc})$ was measured directly in the distal metaphyseal part of the right femur by peripheral quantitative computed tomography (pQCT) adapted for measurements in small animals (Stratec XCT-960A, Stratec, Birkenfeld, Germany). A $360^{\circ}$ X-ray scan, which had a standard thickness of $1 \mathrm{~mm}$ was taken. The scan had a resolution of $0.148 \times 0.148 \mathrm{~mm}$ and was taken at $5.5 \mathrm{~mm}$ from the distal end of the femur, where TBMD of the metaphyseal part was measured. Intra- and interassay variation for the measurements were 3\%. The XCT$960 \mathrm{~A}$ was calibrated with a standard of hydroxyapatite embedded in acrylic plastic.

\section{Statistics}

Statistical analysis was performed by one-way ANOVA for multiple comparison followed by Fisher's PLSD (least significant difference test) test. Values are expressed as 
Table 1 Plasma oestradiol levels and uterine weights of sham-operated and ovariectomized rats receiving various hormonal treatments

\begin{tabular}{|c|c|c|c|}
\hline & Dose & $\begin{array}{l}\text { 17ß-oestradiol plasma } \\
\text { levels }(\mathrm{pg} / \mathrm{ml})\end{array}$ & $\begin{array}{l}\text { Uterine weight } \\
(\mathrm{mg})\end{array}$ \\
\hline \multicolumn{4}{|l|}{ Treatment } \\
\hline SHAM and vehicle & - & $18 \cdot 3 \pm 7 \cdot 2$ & $531 \cdot 1 \pm 21 \cdot 1$ \\
\hline OVX and vehicle & - & $6 \cdot 0 \pm 0 \cdot 7$ & $133 \cdot 5 \pm 11 \cdot 5^{*}$ \\
\hline OVX and EE & $2 \times 2 \cdot 5$ & ND & $380 \cdot 2 \pm 53 \cdot 7^{*} \dagger$ \\
\hline \multirow[t]{2}{*}{ ( $\mu \mathrm{g} /$ rat per day, orally) } & $2 \times 10$ & ND & $443 \cdot 7 \pm 30.0 \cdot * \dagger$ \\
\hline & $2 \times 40$ & ND & $450 \cdot 8 \pm 22 \cdot 6^{*} \dagger$ \\
\hline OVX and $17 \beta$-oestradiol & $2 \times 32$ & $10 \cdot 0 \pm 3 \cdot 7$ & $205 \cdot 9 \pm 19 \cdot 5^{*}$ \\
\hline \multirow[t]{3}{*}{ ( $\mu \mathrm{g} /$ rat per day, orally) } & $2 \times 125$ & $11 \cdot 8 \pm 2 \cdot 4$ & $396 \cdot 9 \pm 28 \cdot 0^{*} \dagger$ \\
\hline & $2 \times 250$ & $18 \cdot 3 \pm 0 \cdot 6$ & $378 \cdot 2 \pm 21 \cdot 9^{*} \dagger$ \\
\hline & $2 \times 500$ & $37 \cdot 1 \pm 5 \cdot 3^{*} \dagger$ & $468 \cdot 4 \pm 28 \cdot 5^{*} \dagger$ \\
\hline $\begin{array}{l}\text { OVX and } 17 \beta \text {-oestradiol } \\
(\mu \mathrm{g} / \text { rat per day, s.c.) }\end{array}$ & $2 \times 2 \cdot 5$ & ND & $514 \cdot 7 \pm 25 \cdot 1 \dagger$ \\
\hline $\begin{array}{l}\text { SHAM and ICI } 164,384 \\
\text { (mg/rat per day, s.c.) }\end{array}$ & $2 \times 2$ & $244 \pm 102 \cdot 0^{*}$ & $173 \cdot 3 \pm 7 \cdot 3^{*}$ \\
\hline OVX and progestagen (Org 2058) & $2 \times 2 \cdot 5$ & ND & $150 \cdot 0 \pm 6 \cdot 8^{*}$ \\
\hline \multirow[t]{2}{*}{ ( $\mu \mathrm{g} / \mathrm{rat}$ per day, s.c.) } & $2 \times 10$ & ND & $161 \cdot 0 \pm 12 \cdot 2^{*}$ \\
\hline & $2 \times 40$ & ND & $155 \cdot 4 \pm 12 \cdot 5^{\star}$ \\
\hline $\begin{array}{l}\text { SHAM and RU } 486 \\
\text { (mg/rat per day, orally) }\end{array}$ & $2 \times 2$ & $29 \cdot 5 \pm 11 \cdot 5$ & $530 \cdot 3 \pm 65 \cdot 6$ \\
\hline $\begin{array}{l}\text { OVX and progestagen and EE } \\
\text { (ug/rat per day, s.c. and orally respectively) }\end{array}$ & $\begin{array}{l}2 \times 40 \text { and } \\
2 \times 40\end{array}$ & ND & $404 \cdot 2 \pm 12 \cdot 7^{*} \dagger$ \\
\hline $\begin{array}{l}\text { OVX and tibolone } \\
(\mu \mathrm{g} / \mathrm{rat} \text { per day, orally) }\end{array}$ & $2 \times 500$ & $7 \cdot 1 \pm 2 \cdot 4$ & $379 \cdot 9 \pm 11 \cdot 0^{*} \dagger$ \\
\hline
\end{tabular}

*Significant versus SHAM $(P<0 \cdot 05)$; †significant versus OVX (P<0·05). ICI164,384, anti-oestrogen; RU 486, anti-progesterone; ND, not determined.

percentage \pm S.E.M. of the mean value measured for the sham-operated group. Statistical analysis was performed for each group to the corresponding sham-operated or ovariectomized group within that experiment and values were considered to be significantly different if $P<0 \cdot 05$.

\section{Results}

In all experiments, OVX induced statistically significant decreases in uterine weight (Table 1 ), $\mathrm{NO}_{3}+\mathrm{NO}_{2}$ plasma levels (Figs 1A, 2A, 3A and 4A) and TBMD (Figs 1B, 2B, $3 \mathrm{~B}$ and $4 \mathrm{~B})$. Four weeks after surgery, the mean plasma $\mathrm{NO}_{3}+\mathrm{NO}_{2}$ levels of the sham-operated and ovariectomized groups were $33 \cdot 6 \pm 1 \cdot 8 \mu \mathrm{M}$ (range 26.1-40.0) and $23 \cdot 1 \pm 0 \cdot 8 \mu \mathrm{M}$ (range $21 \cdot 3-24 \cdot 3$ ) respectively. The mean TBMD values of the sham-operated and ovariectomized groups were $339 \cdot 1 \pm 28 \cdot 4 \mathrm{mg} / \mathrm{cc}$ (range $256 \cdot 1-461 \cdot 7$ ) and $166 \cdot 5 \pm 23 \cdot 4 \mathrm{mg} / \mathrm{cc}$ (range $104 \cdot 0-245 \cdot 1$ ) respectively.

Treatment of ovariectomized rats with EE prevented the decrease in uterine weight (Table 1), $\mathrm{NO}_{3}+\mathrm{NO}_{2}$ plasma levels and TBMD in a dose-dependent manner (Fig. 1). This effect was statistically significant with EE doses $2 \times 10 \mu \mathrm{g} / \mathrm{rat} /$ day or higher.

Treatment of ovariectomized rats with oral $17 \beta$ oestradiol (up to $2 \times 500 \mu \mathrm{g} / \mathrm{rat} /$ day) was associated with a dose-dependent increase in plasma oestrogen level, uterine weight (Table 1), and TBMD (Fig. 2B). This treatment, however, did not prevent the decrease in plasma $\mathrm{NO}_{3}+\mathrm{NO}_{2}$ levels induced by OVX (Fig. 2A). In contrast, administration of $17 \beta$-oestradiol subcutaneously $(2 \times 2.5 \mu \mathrm{g} / \mathrm{rat} /$ day $)$ prevented the decrease in uterine weight (Table 1) and TBMD (Fig. 2B) in addition to the decrease in plasma $\mathrm{NO}_{3}+\mathrm{NO}_{2}$ levels in the ovariectomized rats (Fig. 2A).

The anti-oestrogen ICI164,384 $(2 \times 2 \mathrm{mg} / \mathrm{rat} /$ day, s.c. $)$ given to sham-operated rats reduced uterine weights (Table 1) and TBMD (Fig. 2B) compared with shamoperated rats treated with control solution, but had no effect on the plasma levels of $\mathrm{NO}_{3}+\mathrm{NO}_{2}$ (Fig. 2A). As expected, plasma oestrogen levels of rats treated with ICI164,384 increased by about 13-fold (Table 1).

A discrepancy between plasma $\mathrm{NO}_{3}+\mathrm{NO}_{2}$ levels and TBMD was also found after progestagen treatment. Progestagen $(2 \times 40 \mu \mathrm{g} / \mathrm{rat} / \mathrm{day}$, s.c. $)$ given to ovariectomized rats prevented the decrease in plasma $\mathrm{NO}_{3}+\mathrm{NO}_{2}$ levels in a dose-dependent manner (Fig. 3A), but had no effect on TBMD which remained low (Fig. 3B). As expected, progestagen treatment did not prevent the decrease in uterine weight after OVX (Table 1). Treatment of sham-operated rats with the anti-progestagen RU 486 $(2 \times 2 \mathrm{mg} / \mathrm{rat} /$ day, orally) had no effect on uterine weight (Table 1) and TBMD (Fig. 3B), but tended to decrease plasma $\mathrm{NO}_{3}+\mathrm{NO}_{2}$ levels (Fig. $3 \mathrm{~A}$ ).

Concurrent administration of effective doses of progestagen $(2 \times 40 \mu \mathrm{g} / \mathrm{rat} / \mathrm{day}$, s.c. $)$ and EE $(2 \times 40 \mu \mathrm{g} / \mathrm{rat} /$ day, orally) partly prevented the decrease in plasma $\mathrm{NO}_{3}+\mathrm{NO}_{2}$ levels after OVX (Fig. 4A). This treatment, 

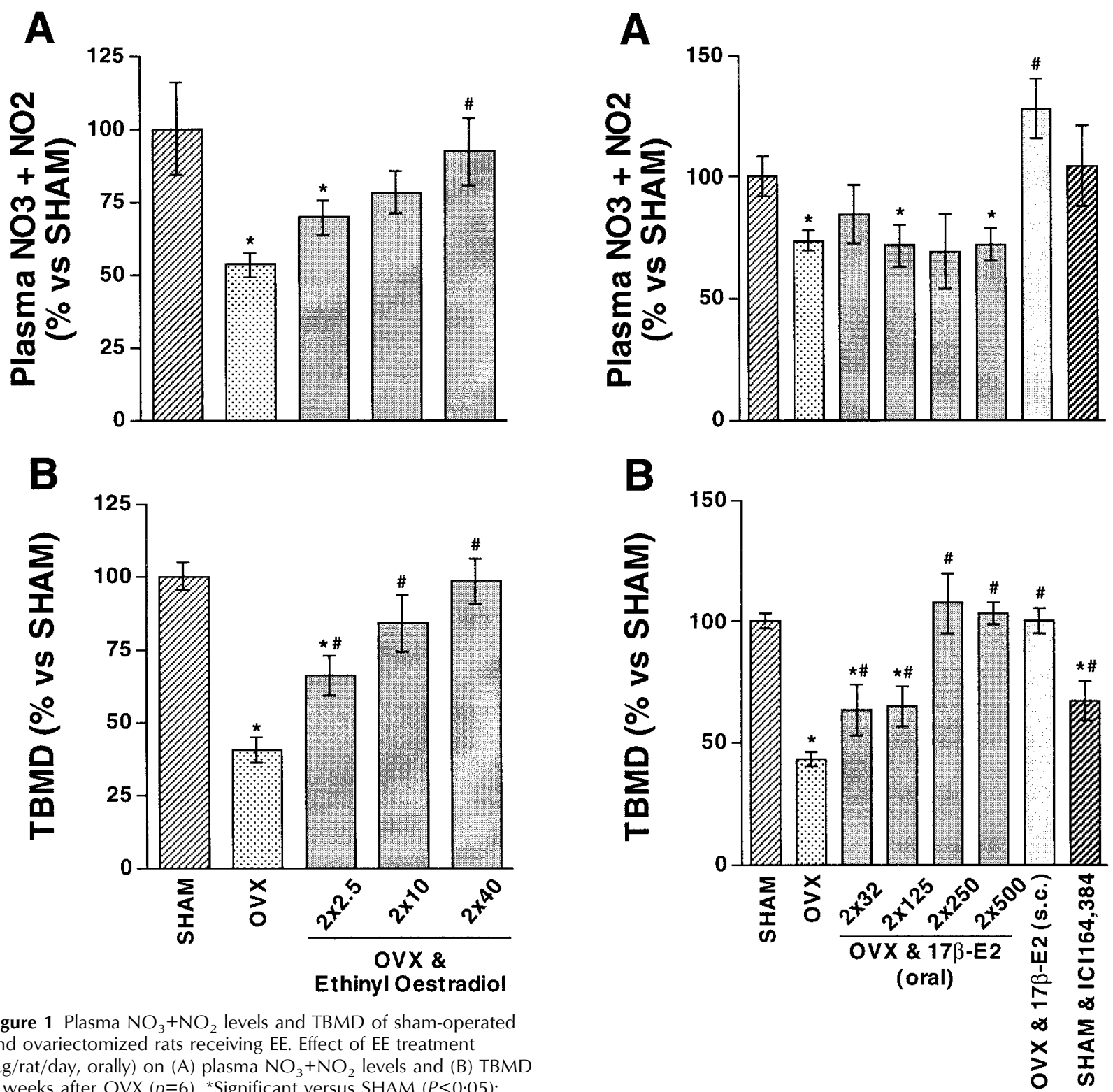

Figure 1 Plasma $\mathrm{NO}_{3}+\mathrm{NO}_{2}$ levels and TBMD of sham-operated and ovariectomized rats receiving $\mathrm{EE}$. Effect of EE treatment $\left(\mu \mathrm{g} / \mathrm{rat} /\right.$ day, orally) on (A) plasma $\mathrm{NO}_{3}+\mathrm{NO}_{2}$ levels and (B) TBMD 4 weeks after OVX $(n=6)$. *Significant versus SHAM $(P<0 \cdot 05)$; \#Significant versus OVX $(P<0 \cdot 05)$. SHAM, sham-operation.

however, prevented the decrease in uterine weight (Table 1) and TBMD (Fig. 4B) in ovariectomized rats. Treatment of ovariectomized rats with tibolone $(2 \times 500 \mu \mathrm{g} / \mathrm{rat} /$ day, orally), a synthetic steroid with combined weak oestrogenic, progestagenic, and androgenic properties, prevented partly the OVX-induced decrease in plasma $\mathrm{NO}_{3}+\mathrm{NO}_{2}$ levels (Fig. 4A) and totally the decrease in TBMD (Fig. 4B). Tibolone had a partial effect on uterine weight after OVX (Table 1).

The effects of the various hormonal treatments on both plasma $\mathrm{NO}_{3}+\mathrm{NO}_{2}$ levels and TBMD are summarized in Table 2.

Figure 2 Plasma $\mathrm{NO}_{3}+\mathrm{NO}_{2}$ levels and TBMD of sham-operated and ovariectomized rats receiving $17 \beta$-oestradiol or anti-oestrogen. Effect of $17 \beta$-oestradiol (orally or s.c., $\mu \mathrm{g} / \mathrm{rat} / \mathrm{day}$ ) and antioestrogen (s.c, mg/rat/day) treatment on (A) plasma $\mathrm{NO}_{3}+\mathrm{NO}_{2}$ levels and (B) TBMD 4 weeks after surgery. SHAM, $n=24$; OVX, $n=20 ; \mathrm{OVX}$ and $17 \beta-\mathrm{E} 2(2 \times 32), n=5 ; \mathrm{OVX}$ and $17 \beta-\mathrm{E} 2$ $(2 \times 125), n=5$; OVX and $17 \beta$-E2 $(2 \times 250), n=4$; OVX and $17 \beta$-E2 $(2 \times 500) n=10$; OVX and $17 \beta$-E2 (s.C., $2 \times 2 \cdot 5), n=8$; SHAM and anti-oestrogen (ICl164,384, $2 \times 2), n=6$. *Significant versus SHAM $(P<0 \cdot 05)$; \#Significant versus OVX $(P<0 \cdot 05)$. $17 \beta-E 2,17 \beta$-oestradiol; SHAM, sham-operation; Data from four experiments.

\section{Discussion}

Previous studies in premenopausal women have shown that plasma $\mathrm{NO}_{3}+\mathrm{NO}_{2}$ levels increase during follicular 

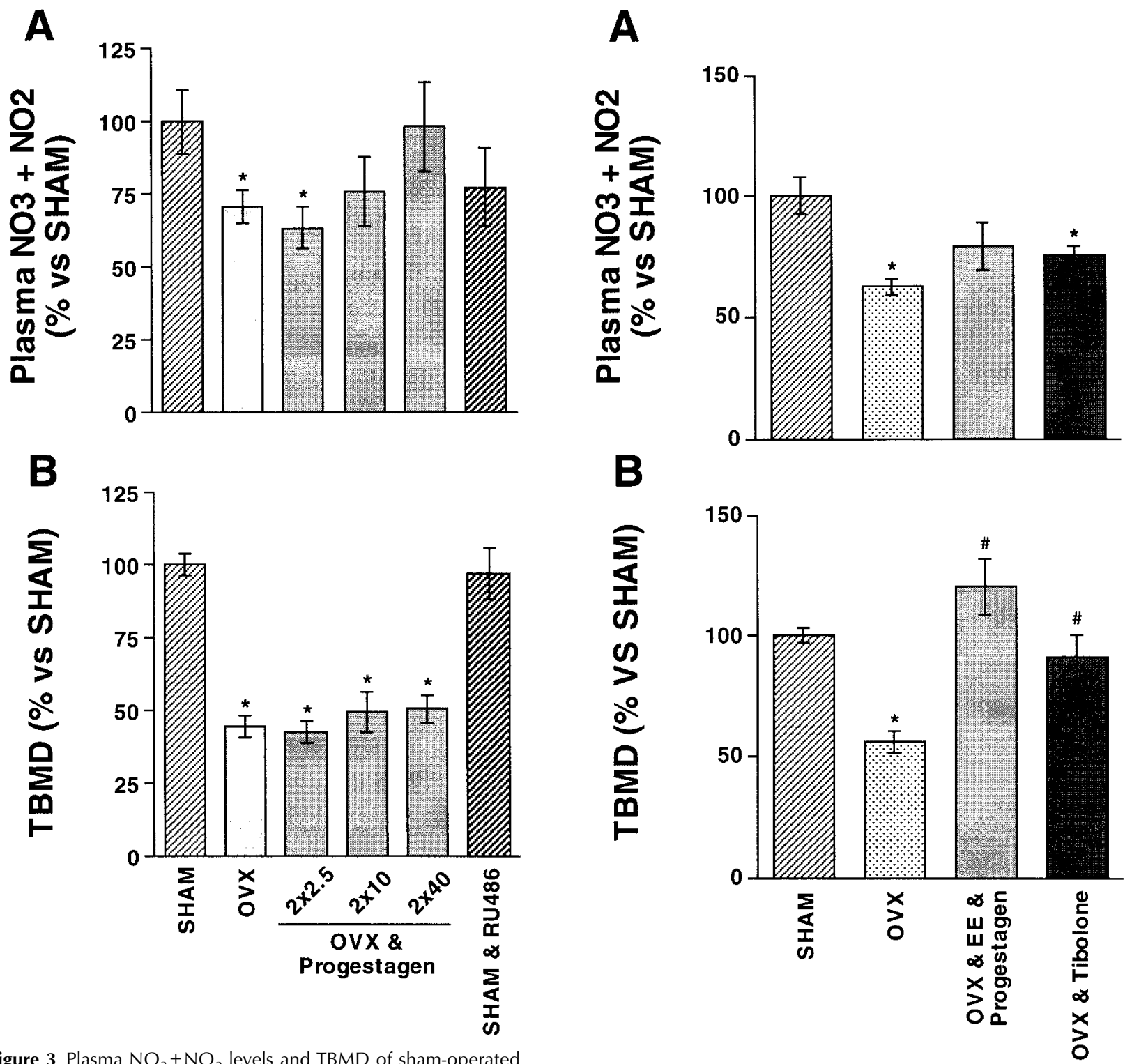

Figure 3 Plasma $\mathrm{NO}_{3}+\mathrm{NO}_{2}$ levels and TBMD of sham-operated and ovariectomized rats receiving progestagen or antiprogesterone. Effect of progestagen $(\mu \mathrm{g} / \mathrm{rat} /$ day, s.c.) and anti-progesterone (RU 486, $2 \times 2 \mathrm{mg} / \mathrm{rat} /$ day, orally) treatment on (A) plasma $\mathrm{NO}_{3}+\mathrm{NO}_{2}$ levels and (B) TBMD 4 weeks after surgery. SHAM, $n=12$; OVX, $n=12$; OVX and progestagen, $n=6$; SHAM and RU 486, $n=6$. *Significant versus SHAM $(P<0 \cdot 05)$; RU 486, anti-progesterone; SHAM, sham-operation. Data from two experiments.

development, peak at mid cycle and are correlated with plasma 17 $\beta$-oestradiol levels (Rosselli et al. 1994, Cicinelli et al. 1996, Kawano et al. 1996). In addition, peak expiratory NO concentrations were found to be significantly higher at mid cycle than during menstruation (Kharitonov et al. 1994). Postmenopausal women, on the other hand, had lower plasma $\mathrm{NO}_{3}+\mathrm{NO}_{2}$ levels;

Figure 4 Plasma $\mathrm{NO}_{3}+\mathrm{NO}_{2}$ levels and TBMD of sham-operated and ovariectomized rats receiving progestagen in combination with $\mathrm{EE}$ or tibolone. Effect of treatment with progestagen $(2 \times 40 \mu \mathrm{g} / \mathrm{rat} /$ day, s.c. $)$ in combination with $\mathrm{EE}(2 \times 40 \mu \mathrm{g} / \mathrm{rat} / \mathrm{day}$, orally), or treatment with tibolone $(2 \times 500 \mu \mathrm{g} /$ day/rat, orally $)$ on (A) plasma $\mathrm{NO}_{3}+\mathrm{NO}_{2}$ levels and (B) TBMD 4 weeks after OVX. SHAM, $n=18$; OVX, $n=16$; OVX and progestagen and $\mathrm{EE}, n=6$; OVX and tibolone, $n=12$. Significant versus SHAM $(P<0 \cdot 05)$; \#Significant versus OVX $(P<0 \cdot 05)$. SHAM, sham-operation. Data from three experiments.

$20 \cdot 2 \pm 2 \cdot 4 \mu \mathrm{M}$ compared with $38 \pm 3 \cdot 0 \mu \mathrm{M}$ in premenopausal women (Rosselli et al. 1995). The latter differences are very similar to those found in the present study between ovariectomized and sham-operated rats $(23 \cdot 1 \pm 0.8 \mu \mathrm{M}$ versus $33 \cdot 6 \pm 1 \cdot 8 \mu \mathrm{M})$. Taken together, 
Table 2 Effects of various hormonal treatments on $\mathrm{NO}_{3}+\mathrm{NO}_{2}$ plasma levels and TBMD in rats

\begin{tabular}{|c|c|c|}
\hline & $\begin{array}{l}\mathrm{NO}_{3}+\mathrm{NO}_{2} \\
\text { plasma levels }\end{array}$ & TBMD \\
\hline \multicolumn{3}{|l|}{ Treatment } \\
\hline OVX and vehicle & $\downarrow$ & $\downarrow \downarrow$ \\
\hline OVX and EE & $=$ & $=$ \\
\hline OVX and $17 \beta$-oestradiol (oral) & $\downarrow$ & $=$ \\
\hline OVX and $17 \beta$-oestradiol (s.c.) & $=$ & $=$ \\
\hline SHAM and anti-oestrogen & $=$ & $\downarrow$ \\
\hline OVX and progestagen & $=$ & $\downarrow$ \\
\hline SHAM-operation and anti-progesterone & $\downarrow$ & $=$ \\
\hline $\mathrm{OVX}$ and progestagen and $\mathrm{EE}$ & $\downarrow$ & $=$ \\
\hline OVX and tibolone & $\downarrow$ & $=$ \\
\hline
\end{tabular}

Compared to SHAM: no change (=); partially decreased $(\downarrow)$; decreased $(\downarrow \downarrow)$.

these results strongly suggest that $\mathrm{NO}_{3}+\mathrm{NO}_{2}$ plasma levels are regulated by ovarian steroids. In addition, in all experiments OVX was associated with parallel decreases in plasma $\mathrm{NO}_{3}+\mathrm{NO}_{2}$ levels and in TBMD.

Plasma $\mathrm{NO}_{3}+\mathrm{NO}_{2}$ levels have been found to reflect endogenous $\mathrm{NO}$ production in humans receiving a low $\mathrm{NO}_{3}+\mathrm{NO}_{2}$ diet (Hibbs et al. 1992). In rats, lipopolysaccharide (LPS) treatment induced an increase in $\mathrm{NO}_{3}+\mathrm{NO}_{2}$ plasma levels that was prevented by L-NAME, suggesting that $\mathrm{NO}_{3}+\mathrm{NO}_{2}$ plasma levels reflect endogenous NO production (Shultz \& Raij 1992). The short half-life of approximately $5 \mathrm{~h}$ of $\mathrm{NO}_{3}$ in plasma (Wagner et al. 1983) and the excretion of dietary $\mathrm{NO}_{3}$ in the urine within $18 \mathrm{~h}$ of intake (Wasserman 1978), allowed us to determine the plasma $\mathrm{NO}_{3}+\mathrm{NO}_{2}$ levels after an overnight fasting period in rats receiving a regular diet. Indeed, the plasma $\mathrm{NO}_{3}+\mathrm{NO}_{2}$ levels $(33.6 \pm$ $1 \cdot 8 \mu \mathrm{M})$ in sham-operated rats in the present study are in agreement with plasma concentrations $(38 \mu \mathrm{M})$ in virgin rats receiving a low $\mathrm{NO}_{3}+\mathrm{NO}_{2}$ diet or a regular diet with sampling about $12 \mathrm{~h}$ after eating (Conrad et al. 1993).

Wimalawansa et al. (1996) postulated recently that a decrease in NO production contributes to bone loss following OVX in rats as treatment of ovariectomized rats with the NO donor nitroglycerine was shown to prevent bone loss. In addition, administration of the NOS inhibitor L-NAME abolished the preventive effect of $17 \beta$-oestradiol on bone loss, while it had no effect when given alone. Kasten et al. (1994), however, previously reported that inhibition of NOS by the relatively specific inducible NOS inhibitor aminoguanidine (Misko et al. 1993, Joly et al. 1994) decreased BMD regardless of oestrogen status in rats. In addition, administration of aminoguanidine to rats decreased BMD (Tsukahara et al. 1996) and reduced bone formation rate (Turner et al. 1997). The NOS inhibitors L-NMMA and L-NAME prevented the increase in cancellous bone formation by mechanical stimulation in rats (Fox et al. 1996, Turner et al. 1996). These findings raise the question whether the modulation in NO pro- duction induced by ovarian steroids and the subsequent changes in BMD are related. In the present study, we addressed this issue by measuring plasma $\mathrm{NO}_{3}+\mathrm{NO}_{2}$ levels and TBMD in rats receiving various hormonal treatments.

Treatment with oral EE or subcutaneous $17 \beta$-oestradiol increased plasma $\mathrm{NO}_{3}+\mathrm{NO}_{2}$ levels following OVX in rats - a result that is similar to the increase in plasma $\mathrm{NO}_{3}+\mathrm{NO}_{2}$ levels reported after treatment of postmenopausal women with transdermal $17 \beta$-oestradiol (Rosselli et al. 1995) or premenopausal women with a non-specified oestrogen preparation (Ramsay et al. 1995). Both oral $\mathrm{EE}$ or subcutaneous $17 \beta$-oestradiol also prevented the decrease in TBMD following OVX in rats. However, treatment with oral $17 \beta$-oestradiol up to $2 \times 500 \mu \mathrm{g} / \mathrm{rat} /$ day, while exerting all expected oestrogenic effects on uterine weight and TBMD, had no effect on plasma $\mathrm{NO}_{3}+\mathrm{NO}_{2}$ levels which remained at the OVX level. This may be due to differences in the activities of metabolites of $17 \beta$-oestradiol generated after passage of the liver on uterus and bone and on cells responsible for endogenous NO production. EE is relatively slowly transformed into inactive metabolites in the liver (Kuhl 1990) and may, therefore, be active on endogenous $\mathrm{NO}$ production after oral administration.

Treatment with the anti-oestrogen ICI164,384 diminished TBMD to about half the decrease seen after OVX and decreased uterine weight to a level similar to that found in ovariectomized rats. Anti-oestrogen treatment, however, had no effect on plasma $\mathrm{NO}_{3}+\mathrm{NO}_{2}$ levels. These results also revealed a dissociation between circulating $\mathrm{NO}_{3}+\mathrm{NO}_{2}$ plasma levels and TBMD. While there was a clear relation between the changes in oestrogen plasma levels and TBMD, the present data suggest that another ovarian steroid besides oestrogen may be involved in the regulation of plasma $\mathrm{NO}_{3}+\mathrm{NO}_{2}$ levels. This may be progesterone, as progestagen treatment prevented the OVX-induced decrease in $\mathrm{NO}_{3}+\mathrm{NO}_{2}$ dose-dependently. In humans, progesterone serum levels did not correlate with $\mathrm{NO}_{3}+\mathrm{NO}_{2}$ plasma levels (Rosselli et al. 1994), but most of the progesterone plasma concentrations in that study were within a narrow range $(1-3 \mathrm{nM})$. In later studies by the same group, treatment of postmenopausal women with both oestrogen and progesterone induced a slight elevation in plasma $\mathrm{NO}_{3}+\mathrm{NO}_{2}$ levels, while oestrogen alone increased these levels significantly (Rosselli et al. 1995, Imthurn et al. 1997). Plasma $\mathrm{NO}_{3}+\mathrm{NO}_{2}$ levels are lower in the secretory phase of the menstrual cycle than at the mid cycle and it has been suggested that this may be due to increased progesterone production during the secretory phase (Cicinelli et al. 1996, Kawano et al. 1996). These observations correspond well with the finding in the present study that concurrent administration of oestrogen and progestagen to ovariectomized rats partly prevented the decrease in plasma $\mathrm{NO}_{3}+\mathrm{NO}_{2}$ levels. In addition, tibolone, a synthetic steroid with weak oestrogenic, androgenic, and progestational activity (Tax et al. 1987, van der 
Vies 1987), slightly elevated plasma $\mathrm{NO}_{3}+\mathrm{NO}_{2}$ levels in ovariectomized rats but did not prevent the OVX-induced decrease. Taken together, these results suggest that the combination of oestrogen and progesterone decreases plasma $\mathrm{NO}_{3}+\mathrm{NO}_{2}$ levels.

The effect of progesterone on bone is still controversial. Although short term positive effects of progesterone on bone have been reported in both humans (Abdalla et al. 1985, consensus report by Whitehead \& Lobo 1988, reviewed by Prior 1990) and rodents (Barbagallo et al. 1989, Barengolts et al. 1990), other studies failed to demonstrate a positive effect of progesterone (Isserow et al. 1995). While progesterone has been reported to abolish the protective effect of oestrogen against bone mineral loss after OVX in rats (Barbagallo et al. 1989), no negative effect of progestagen on the bone sparing effect of oestrogen was observed in the present study. The available data in humans indicate that the addition of progestagen to oestrogen therapy does not influence the skeletal response (consensus report by Whitehead \& Lobo 1988). Treatment with tibolone completely prevented bone loss after OVX in the present study. This protective effect of tibolone against bone loss has also been reported in postmenopausal women (Lindsay et al. 1980, Fogelman et al. 1981, Rymer et al. 1994, Lyritis et al. 1995, Bjarnason et al. 1996).

In conclusion, OVX decreased both TBMD and plasma $\mathrm{NO}_{3}+\mathrm{NO}_{2}$ levels in rats. These two parameters, however, did not correlate with each other as they were differently affected by various hormonal treatments. While plasma $\mathrm{NO}_{3}+\mathrm{NO}_{2}$ levels were regulated by both oestrogen and progesterone, TBMD was affected by changes in oestrogen levels only. Decreased systemic NO production, therefore, is not involved in bone loss after OVX. It is possible, however, that a reduction in local NO production within the bone microenvironment may be involved.

\section{Acknowledgement}

The authors thank HD Petronilia, M Scheepers, C Spanjers, and A Weekers for their technical assistance.

\section{References}

Abdalla HI, McKay Hart D, Lindsay R, Leggate I \& Hooke A 1985 Prevention of bone mineral loss in postmenopausal women by norethisterone. Obstetrics and Gynecology 66 789-792.

Baulieu EE 1989 Contragestion and other clinical applications of RU 486, an antiprogesterone at the receptor. Science 245 1351-1357.

Barbagallo M, Carbognani A, Palummeri E, Chiavarini M, Pedrazzoni M, Bracchi PG \& Passeri M 1989 The comparative effects of ovarian hormone administration on bone mineral status in oophorectomized rats. Bone 10 113-116.

Barengolts EI, Gajardo HF, Rosol TJ, D’anza JJ, Pena M, Botsis J \& Kukreja SC 1990 Effects of progesterone on postovariectomy bone loss in aged rat. Journal of Bone and Mineral Research 5 1143-1147.
Bjarnason NH, Bjarnason K, Haarbo J, Rosenquist C \& Christiansen C 1996 Tibolone: prevention of bone loss in late postmenopausal women. Journal of Clinical Endocrinology and Metabolism $\mathbf{8 1}$ 2419-2422.

Cicinelli E, Ignarro LJ, Lograno M, Galantino P, Balzano G \& Schonauer LM 1996 Circulating levels of nitric oxide in fertile women in relation to the menstrual cycle. Fertility and Sterility 66 1036-1038.

Conrad KP, Joffe GM, Kruszyna H, Kruszyna R, Rochelle LG, Smith RP, Chavez JE \& Mosher MD 1993 Identification of increased nitric oxide biosynthesis during pregnancy in rats. FASEB Journal 7 566-571.

Damoulis PD \& Hauschka PV 1994 Cytokines induce nitric oxide production in mouse osteoblasts. Biochemical and Biophysical Research Communications 201 924-931.

Fogelman I, Bessent RR, Smith ML, Hart DM \& Lindsay R 1981 Assessment of synthetic steroid (Org OD14): effect on skeletal metabolism by $24 \mathrm{~h}$ whole-body retention of disphosphonate. Maturitas 3 265-269.

Fox SW, Chambers TJ \& Chow JWM 1996 Nitric oxide is an early mediator of the increase in bone formation by mechanical stimulation. American Journal of Physiology 270 E955-E960.

Green LC, Wagner DA, Glogowski J, Skipper PL, Wishnok JS \& Tannanbaum SR 1982 Analysis of nitrate, nitrite, and $\left[{ }^{15} \mathrm{~N}\right]$ nitrate in biological fluids. Analytical Biochemistry 126 131-138.

Hayashi T, Fukuto JM, Ignarro LJ \& Chaudhuri G 1992 Basal release of nitric oxide from aortic rings is greater in female rabbits than in male rabbits: implications for atherosclerosis. Proceedings of the National Academy of Sciences of the USA 89 11259-11263.

Hayashi T, Yamada K, Esaki T, Kuzuya M, Satake S, Ishikawa, Hidaka H \& Iguchi A 1995 Oestrogen increases endothelial nitric oxide by a receptor-mediated system. Biochemical and Biophysical Research Communications 214 847-855.

Hibbs JB, Westenfelder C, Taintor R, Vavrin Z, Kablitz C, Baranowski RL, Ward JH, Menlove RL, McMurray MP, Kushner JP \& Samlowski WE 1992 Evidence for cytokine-inducible nitric oxide synthesis from L-arginine in patients receiving interleukin-2 therapy. Journal of Clinical Investigation 89 867-877.

Hukkanen M, Hughes FJ, Buttery LDK, Gross SS, Evans TJ, Seddon S, Riveros-Moreno V, MacIntyre I \& Polak JM 1995

Cytokine-stimulated expression of inducible nitric oxide synthase by mouse, rat, and human osteoblast-like cells and its functional role in osteoblast metabolic activity. Endocrinology 136 5445-5453.

Imthurn B, Rosselli M, Jaeger AW, Keller PJ \& Dubey RK 1997 Differential effects of hormone-replacement therapy on endogenous nitric oxide (nitrite/nitrate) levels in postmenopausal women substituted with $17 \beta$-oestradiol valerate and cyproterone acetate or medroxyprogesterone acetate. Journal of Clinical Endocrinology and Metabolism 82 388-394.

Isserow JA, Rucinski B, Romero DF, Mann GN, Liu CC \& Epstein S 1995 The effect of medroxyprogesterone acetate on bone metabolism in the oophorectomized, tamoxifen-treated rat. Endocrinology 136 713-719.

Joly GA, Ayres M, Chelly F \& Kilbourn RG 1994 Effects of $\mathrm{N}^{\mathrm{G}}$-methyl-L-arginine, $\mathrm{N}^{\mathrm{G}}$-nitro-L-arginine, and aminoguanidine on constitutive and inducible nitric oxide synthase in rat aorta. Biochemical and Biophysical Research Communications 199 147-154.

Kasten TP, Collin-Osdoby P, Patel N, Osdoby P, Krukowski M, Misko TP, Settle SL, Currie MG \& Nickols GA 1994 Potentiation of osteoclast bone-resorption activity by inhibition of nitric oxide synthase. Proceedings of the National Academy of Sciences of the USA 91 3569-3573.

Kawano H, Motoyama K, Kugiyama K, Hirashima O, Ohgushi M, Yoshimura M, Ogawa H, Okumura K \& Yasue H 1996 Menstrual cyclic variation of endothelium-dependent vasodilation of the brachial artery: possible role of oestrogen and nitric oxide. Proceedings of the Association of American Physicians 108 473-480. 
Kharitonov SA, Logan-Sinclair RB, Busset CM \& Shinebourne EA 1994 Peak expiratory nitric oxide differences in men and women: relation to the menstrual cycle. British Heart Journal 72 243-245.

Kuhl H 1990 Pharmacokinetics of oestrogens and progestogens. Maturitas 12 171-197.

Lindsay R, Hart DM \& Kraszewski A 1980 Prospective double-blind trial of synthetic steroid (Org OD14) for preventing postmenopausal osteoporosis. British Medical Journal 280 1207-1209.

Löwik CWGM, Nibbering PH, van de Ruit M \& Papapoulos SE 1994 Inducible production of nitric oxide in osteoblast-like cells and in fetal mouse bone explants is associated with suppression of osteoclastic bone resorption. Journal of Clinical Investigation $\mathbf{9 3}$ 1465-1472.

Lyritis GP, Karpathios S, Basdekis K, Grigoriou O, Katostaras T, Paspati T, Stamatopoulos T, Siampalioti G \& Lyritis PG 1995 Prevention of post-oophorectomy bone loss with tibolone. Maturitas 22 247-253.

MacIntyre I, Zaidi M, Alam ASMT, Datta HK, Moonga BS, Lidbury PS, Hecker M \& Vane JR 1991 Osteoclastic inhibition: an action of nitric oxide not mediated by cyclic GMP. Proceedings of the National Academy of Sciences of the USA 88 2936-2940.

Misko TP, Moore WM, Kasten TP, Nickols GA, Corbett JA, Tilton RG, McDaniel ML, Williamson JR \& Currie MG 1993 Selective inhibition of the inducible nitric oxide by aminoguanidine. European Journal of Pharmacology 233 119-125.

Prior JC 1990 Progesteron as a bone-tropic hormone. Endocrine Reviews 11 386-398.

Ralston SH \& Grabowski PS 1996 Mechanisms of cytokine induced bone resorption: role of nitric oxide, cyclic guanosine monophosphate, and prostaglandins. Bone 19 29-33.

Ralston SH, Todd D, Helfrich M, Benjamin N \& Grabowski PS 1994 Human osteoblast-like cells produce nitric oxide and express inducible nitric oxide synthase. Endocrinology 135 330-336.

Ralston SH, Ho LP, Helfrich MH, Grabowski PS, Johnston PW \& Benjamin N 1995 Nitric oxide: a cytokine-induced regulator of bone-resorption. Journal of Bone and Mineral Research 10 1040-1049.

Ramsay B, Johnson MR, Leone AM \& Steer PJ 1995 The effect of exogenous oestrogen on nitric oxide production in women: a placebo controlled crossover study. British Journal of Obstetrics and Gynaecology 102 417-419.

Riancho JA, Salas E, Zarrabeitia MT, Olmos JM, Amado JA, Fernández-Luna JL \& González-Macías J 1995 Expression and functional role of nitric oxide synthase in osteoblast-like cells. Journal of Bone and Mineral Research 10 439-446.

Rosselli M, Imthurm B, Macas E, Keller PJ \& Dubey RK 1994 Circulating nitrite/nitrate levels increase with follicular development: indirect evidence for oestradiol mediated NO release. Biochemical and Biophysical Research Communications 202 1543-1552.

Rosselli M, Imthurn B, Keller PJ, Jackson EK \& Dubey RK 1995 Circulating nitric oxide (nitrite/nitrate) levels in postmenopausal women substituted with $17 \beta$-oestradiol and norethisterone acetate: a two-year follow-up study. Hypertension 25 848-853.
Rymer J, Chapman MG \& Fogelman I 1994 Effect of tibolone on postmenopausal bone loss. Osteoporosis International 4 314-319.

Shultz PJ \& Raij L 1992 Endogenously synthesized nitric oxide prevents endotoxin-induced glomerular thrombosis. Journal of Clinical Investigation 90 1718-1725.

Stern PH \& Diamond J 1992 Sodium nitroprusside increases cyclic GMP in fetal rat bone cells and inhibits resorption of fetal rat limb bones. Research Communications in Chemical Pathology and Pharmacology 75 19-28.

Tax L, Goorissen EM \& Kicovic PM 1987 Clinical profile of Org OD14. Maturitas 9 3-13.

Tsukahara H, Miura M, Tsuchida S, Hata I, Hata K, Yamamoto K, Ishii Y, Muramatsu I \& Sudo M 1996 Effect of nitric oxide inhibitors on bone metabolism in growing rats. American Journal of Physiology 270 E840-E845.

Turner HC, Takano Y, Owan I \& Murrell GAC 1996 Nitric oxide inhibitor L-NAME suppresses mechanically induced bone formation in rats. American Journal of Physiology 270 E634-E639.

Turner HC, Owan I, Jacob DS, McClintock R \& Peacock M 1997 Effects of nitric oxide synthase inhibitors on bone formation in rats. Bone 21 487-490.

Vies van der J 1987 Pharmacological studies with (7 alpha,17 alpha)-17-hydroxy-7-methyl-19-norpregn-5(10)-en-2-yn-3-on (Org OD14). Maturitas (Suppl 1) 15-24.

Visser de J, Coert A, Feenstra H \& Vies van der J 1984 Endocrinological studies with $(7 \alpha, 17 \alpha)$-17-hydroxy-7-methyl-19norpregn-5(10)-en-20-yn-3-one (Org OD14). Arzneimittel Forschung/Drug Research 34 1010-1017.

Wagner DA, Schultz DS, Deen WM, Young VR \& Tannenbaum SR 1983 Metabolic fate of an oral dose of ${ }^{15} \mathrm{~N}$-labeled nitrate in humans: effect of diet supplementation with ascorbic acid. Cancer Research 43 1921-1925.

Wakeling AE \& Bowler J 1987 Steriodal pure antioestrogens. Journal of Endocrinology 112 R7-R10.

Wasserman AE 1978 The nitrate-nitrosamine situation: a review. Food Engineering 50 110-116.

Weiner CP, Lizasoain I, Baylis SA, Knowles RG, Charles IG \& Moncada S 1994 Induction of calcium-dependent nitric oxide synthases by sex hormones. Proceedings of the National Academy of Sciences of the USA 91 5212-5216.

Whitehead M \& Lobo RA 1988 Progestagen use in postmenopausal women. Lancet 26 1243-1244.

Wimalawansa SJ, De Marco G, Gangula P \& Yallampalli C 1996 Nitric oxide donor alleviates ovariectomy-induced bone loss. Bone 18 301-304.

Yallampalli C, Byam-Smith M, Nelson SO \& Garfield RE 1994 Steroid hormones modulate the production of nitric oxide and cGMP in the rat uterus. Endocrinology 134 1971-1974.

Received 26 January 1998

Accepted 30 April 1998 